\title{
TALENT RETENTION: A MEDIATOR OF THE RELATIONSHIP BETWEEN TALENT MANAGEMENT STRATEGIES AND SUCCESSION PLANNING
}

\author{
Poonam Jindal ${ }^{*}$ and Mohsin Shaikh ${ }^{2}$ \\ ${ }^{I}$ Vignana Jyothi Institute of Management, Hyderabad, Telangana 500090, India \\ ${ }^{2}$ ASM Institute of Professional Studies, No. 29/1+2A, CTS No. 4695, Wing-B, \\ Old Mumbai Rd, Pimpri Colony, Pune, Maharashtra 411018, India \\ ${ }^{*}$ Corresponding author: poonampradhaan@gmail.com
}

Published online: 1 December 2021

To cite this article: Jindal, P., \& Shaikh, M. (2021). Talent retention: A mediator of the relationship between talent management strategies and succession planning. Asian Academy of Management Journal, 26(2), 117-142. https://doi.org/10.21315/aamj2021 .26.2.6

To link to this article: https://doi.org/10.21315/aamj2021.26.2.6

\begin{abstract}
Succession planning is becoming a focus point for discussion in business world as very few organisations are prepared with their successors for occupying the position as and when it is needed. With special reference to Indian pharmaceutical companies, where talent is critical and rare in nature, this becomes a more crucial requirement. This paper, by integrating theory of Internal Labour Market (ILM), deals with the relationship among talent identification (TID), talent development (TD), talent retention (TR), and succession planning in Indian pharmaceutical companies. A survey method was used for collecting the response of senior level managers of pharmaceutical companies located in Hyderabad, India, and the hypothetical model and structural relationships were tested via structural equation modelling (SEM). The findings of the research present that TR plays a role of mediator in the relationship of TID, TD and succession planning in organisations. This study helps pharmaceutical companies to be future ready for succession planning by using their regular talent management strategies skilfully. This study beautifully develops an empirical relationship between TID, TD, and succession planning with the mediating effect of TR. Research also brings out the theoretical importance of ILM theory. This, as per best of researchers' knowledge, was not presented in earlier research on talent management or on succession planning.
\end{abstract}

Keywords: succession planning, talent management strategies, internal labour market theory, structural equation modelling, talent retention

(C) Asian Academy of Management and Penerbit Universiti Sains Malaysia, 2021. This work is licensed under the terms of the Creative Commons Attribution (CC BY) (http://creativecommons. org/licenses/by/4.0/). 


\section{INTRODUCTION}

Succession planning encompasses the identification of key organisational resources (Orellano \& Miller, 1997) as per the organisational requirement (Hall, 1986). In the current business world, best talent is the need of every organisation and succession planning becomes the tool to ensure that possibility for organisations. Succession planning not only saves the cost of recruiting and time for hiring new employees (Adebola, 2019), it also improves the employee commitment and loyalty towards organisation. Succession planning directly may look like an exercise of leadership pool development, but indirectly it has impact on employee's morale and engagement as well. Ultimately succession planning helps in developing leaders and retaining the talent pool for companies (Bolander et al., 2017). It becomes more relevant being on time in terms of occupying the right position at the right time especially for leadership positions in pharma companies (Leslie \& Palmisano, 2014). There are various reasons to find the gap between the requirement of leaders and actual availability of people to fill that gap (Leibman et al., 1996). In such case, the need for developing and retaining the best talent becomes the strategic goal for all companies. The way is through talent management strategies (TMS) - talent identification (TID), talent development (TD), and talent retention (TR) for leadership positions (Jindal \& Shaikh, 2017).

Studies reveal that succession planning becomes one of the TMS to retain the best talent (Ali \& Mehreen, 2019) but to our information, past literature has not touched upon TMS influence on succession planning in pharmaceutical companies. Therefore, to fill the gap in research, this study has focused on the relationship between TMS and succession planning for pharmaceutical companies located in Hyderabad, India.

The main objective of the study is to establish a relationship among TMS and succession planning in pharmaceutical companies; how TID, TD, and TR are seen as facilitators in succession planning for leadership or managerial roles. This analysis can help pharmaceutical organisations to focus on and improve TMS and retention strategies in specific to improve the success of succession planning. Therefore, the present study is conducted in Hyderabad which is socalled hub of pharma companies in India. This study provides a roadmap to pharma companies for succession planning by using TMS as tool. The main contribution of this study is to find out a relationship between TMS and succession planning which is empirically proven. Past research indicated that promotional or developmental activities were used for leadership development or transferring workmen on the next level (Pfeifer, 2010), which supports the internal labour 
market (ILM) theory. This study also contributes and builds upon the theory of ILM by connecting the idea of talent management with succession planning. As explained in the theory of ILM developed by Doeringer and Piore (1971), ILM encourages the development of firm specific competencies and proliferating promotions from within. Thus, the present study helps the strategy makers in pharma companies to design successful succession planning by using TMS which later can make them ready to fill the key positions on leadership roles. This paper comes up as extension on various studies being conducted in succession planning by adding empirical evidence about the relationship of TMS and succession planning.

\section{LITERATURE REVIEW AND HYPOTHESES FORMULATION}

\section{Talent Management and Succession Planning}

Although the talent management concept has been the topic for discussion in several forms since World War II, yet, it is argued that the strategic importance of talent management actually recognised when McKinsey's consultants devised the phrase "The War for Talent" in the end of 1990s (Cappelli, 2008; Scullion and Collings, 2011; Axelrod et al., 2002). When the shortage of talent was becoming one big challenge for human resource in companies, this war for talent was recognised and initiated (Mäkelä et al., 2010). Therefore, organisations were advised to focus on systematic approaches to attract, identify, select, develop, and retain talent rather being attentive only in maximising competitiveness (Axelrod et al., 2002; Huselid et al., 2005). A three goals area model by Boxall and Gilbert (2007) represents retention, development, and motivation of managers to manage themselves for senior positions. This model emphasises on the identification, development, and retention of senior managers for the competitive advantage of organisation (Boxall \& Gilbert, 2007). Studies focus on the changed preferences of new generation employees and use of TMS for millennials since they are the huge contributors as resources in current future (Jindal \& Shaikh, 2017; Jindal \& Nalluri, 2019). Talent management plays a key role in creating, developing, and sustaining a competitive advantage for any pharmaceutical company (Bassett et al., 2005). One research indicates that employee engagement is also used as talent retention tool in pharmaceutical companies (Jindal et al., 2017). Study states that satisfied employees create pool of satisfied customers, and the technical expertise of pharmaceutical employees is the key for success of pharmaceutical companies (Majumdar, 2007). Another research indicates that different behavioural training techniques are also used as talent development strategies for developing talent (Jindal \& 
Shaikh, 2015). Earlier research indicated certain strategies like use of social sites for attracting talent and preparing certain talent attraction strategies to fulfil immediate requirements in pharma companies (Jindal \& Shaikh, 2014; Jindal et al., 2017).

"Succession planning is a process every company needs to have to make sure they know where the gaps are, they know what talent they have in place and how to develop them in the upcoming years until the position is ready," as per Larry Brand, Chief of Human Resources Officer for Elkay Manufacturing (https://www.hrexchangenetwork.com). Succession planning firstly is viewed as strategy to work on the damage that may happen because of the loss of key leadership (Rothwell, 2010). Later with the time it is also seen as a process of helping organisation to save cost in hiring and motivating employees to aspire and get ready for leadership position (Groves, 2007). Employees get motivated when they see their career development and pursuit of employment (Fink, 2010). There are many studies on succession planning in family business as well (Yadav \& Shankar, 2017; Gilding et al., 2015; Ghee et al., 2015).

In other studies, the impact of succession planning was also found on other variables such as employee engagement, employee's loyalty, employee turnover, and morale (Sweeney, 2013), whereas few studies say that succession planning can be used as strategy for retention by offering them development opportunities in organisation (Nzuve \& Omolo, 2012). Other studies also focus on relationship between employee performance and succession planning (Ali \& Mehreen, 2019). Shamaila Burney (2016) worked on research describing a model on performance-based succession planning and performance appraisal relationship, where the researcher attempted to help organisations to develop successors based on performance appraisal data gathered. Succession planning is probably possible through developing pools of talent, development of a talent mindset, identifying critical positions, and differentiating between star performers and others in terms of potential and performance (Orellano \& Miller, 1997). Conger and Fulmer (2003) also say that besides these given points, creating essential positions and fulfilling them through non-stop learning by bouncing targets is another strategy of developing leadership pipeline.

Boudreau and Ramstad (2005) say that "talent segmentation" is as important as "customer segmentation." Talent segmentation is the process of recognising the key talent pools, where talent makes the major difference to premeditated success. Succession planning assist organisations for being ready for replacements for key positions when its needed and improves the performance (Rothwell, 2010). Succession planning can ensure the availability of right 
person to fill key positions when they get vacant for any reason such as retirement, resignation, promotions, etc. (Armstrong, 2003). Johnson et al. (2018) examined the role of succession planning in large and small firms. Lately, organisations started focusing on having high potential people at all levels and creating leadership potential at all levels is a wise action (Mehrabani \& Mohamad, 2011). Practically organisations, those are using succession planning as instrument, can predict their sustainability and winning over the competitive edge. If organisations do not have proper succession plan, they may have to suffer with the loss of right talent at right place at right time and probably look for the external hiring as and when they need key people on key positions (Rothwell, 2010). Stuart (2012) also have given similar idea that if Indian organisations do not identify potential talent at every level, they may face difficulty in sustainability. Succession planning focuses on learning opportunities that empowers the employees to work on their career progression (Heiden, 2007).

Many times, talent management is used loosely as succession planning throughout large number of research, whereas Rothwell (2010, pp. 16-17) has explained the difference between the two in his book, "Effective Succession Planning" and use of talent management for succession planning. Talent management term is used to explain the human resource practices which facilitate the succession planning (Lewis \& Heckman, 2006). Talent management is a process that leads to the ultimate strategic goal of succession plan. Talent management is more focused on individuals and its aim is to identify, retain, and develop them, in contrast to that succession planning which is more concerned about satisfying the organisational strategic need (Cannon \& Mcgee, 2010). Research has discussed about establishing talent management for succession planning through analytical network process (Hor et al., 2010), whereas identification and development were used to creating leadership pool, but retention aspect was missing. Hence, that also creates gap for new research.

\section{Talent Identification (TID)}

There are various studies on TID in sports (Johnston et al., 2018; Miller et al., 2015; Sarmento et al., 2018; Webborn et al., 2015) area. In organisational context, TID is the main step of talent management. TID is a substantial affair which shows employee insertion in organisation's talent pool, which later gets development opportunities, and management attention for being part of succession planning (King, 2016). Employee perceives formal TID process as organisational support and has an influence on their turnover intention (Björkman et al., 2013). Employees see TID as an action of employer to recognise 
their contribution and decide about the investments in their future growth (Lee et al., 2011), which also contribute to succession planning. TID is performed to identify the high potential talent for further development (King, 2016). Employees are ranked as "A Players," and identified as top performers (Lewis \& Heckman, 2006; Collings \& Mellahi, 2009; Cappelli, 2008; Huselid et al., $2005)$ to get the place in replacement charts. Research indicates the usefulness of e-human resource management for TID (Wiblen, 2016). The three approaches for TID are intuitive, individualised, and systematic. Individualistic process is often recommended by human resource practitioners because of their belief that few employees are rightly competent (Dries, 2013). Whereas talent management practitioners emphasise on systematic TID for identification of key performers for succession planning (Mellahi \& Collings, 2010; Huselid et al., 2005). In support team selection when coaches take the decision of identifying and selecting athletes based on their intuitions that is referred as "coach's eye," this phenomenon is called intuitive approach (Lath et al., 2021). Organisations, which focus on best practices, identify talent for succession planning and share those leaders across function to invigorate itself (Cohn et al., 2005). TID used as a tool for talent pooling to facilitate succession planning (Lewis \& Heckman, 2006). Kasper (2008) analysed the influence of organisational communication in succession planning programme. The underlying assumption in the current study is that the employees identified for succession planning are aware about their inclusion in the successors list. The research instrument captures information about their knowledge. Item in the demographics section has a question about their awareness of being identified for next development plans for succession, yet the nature of communication is not considered under the scope of this study. Based on many studies on TID and succession planning, the hypothesis is developed as follows:

H1: TID has a direct positive relationship with succession planning.

\section{Talent Development (TD)}

TD is defined as "a process that focuses on the planning, selection, and implementation of development strategies for the entire talent pool to ensure that the organisation has both the current and future supply of talent to meet strategic objectives and that development activities are aligned with organisational talent management processes" (Garavan et al., 2012). Literature indicates that TD is part of talent management which deals with the competency development of employees who are identified through TID process (Novations, 2009, Cappelli, 2009). TD is equally important for global talent management (Scullion \& Collings, 2011). Garavan et al. (2012) explained that organisations need to 
focus on few important questions before planning TD. TD is planned to ensure the continuous development of high potential talent (CIPD, 2011) for making planned succession successful (Gandz, 2006). TD activities can create formal and informal opportunities for employees (Marsick \& Watkins, 2001). Nonformal learning environment is creating opportunities for informal development (Wenger et al., 2002). Under the umbrella of TD, leadership development become the focal point of discussion, which eventually leads to succession planning (Groves, 2007). Best practices used for development are executive coaching, mentoring, 360-degree feedback, etc. (Collins \& Holton, 2004; Day, 2001; Burke \& Day,1986; Kur \& Bunning, 2002). With reference to leaders' development for succession planning, studies indicate the importance of actionoriented development for enhancing competencies which are aligned with organisation's strategic plans (Rothwell, 2002; Charan, 2005). Based on the various studies on TD and succession planning, the following hypothesis is developed:

H2: TD has a direct positive relationship with succession planning.

\section{Talent Retention (TR)}

TR is a challenge for organisation in today's economic world, especially for learning organisation (Bihani \& Dalal, 2014). Companies are using various strategies to retain their best talent. Employee engagement (Jindal et al., 2017), assessment centres, career management (Pandita \& Ray, 2018), rewards and recognition (Tangthong et al., 2014), supportive culture, and supportive leadership (Oladapo, 2014) are used as retention strategies. Beyond anything else, it is the primary need of organisation to retain the best talent (Festing \& Schäfer, 2014). TR requires four main areas to focus which are work atmosphere, compensation, growth prospects, and sufficient support (Ramanaiah \& Lavanya, 2011). Employer branding is another strategy that works positively for TR (Botha et al., 2011). Research has indicated the relation of TR with succession planning in IT sector (Natarajan \& Babu, 2018). Recent past studies also revealed the association of succession planning with employee's turnover intentions in banking sector (Ali \& Mehreen, 2019). O'Gorman (2006) explained that if organisations do not work on retaining key performers, this may affect their financial conditions as well. Succession plan improves retention, reduces attrition, and finds sources for replacements (Atwood, 2007). Retaining the key talent leads to succession planning. Based on this review of research the next hypothesis is developed as follows:

H3: TR has a direct positive relationship with succession planning.

H4: TR works as mediator among TID, TD, and succession planning. 


\section{Theory of Internal Labour Management (ILM)}

Theory of ILM is a classical work of Doeringer and Piore in 1971. ILM supports the idea of developing job specific competencies of employees and promoting employees from within the firm (Baron \& Kreps, 1999). The idea of developing competencies and promoting employees within the organisation can be seen in TMS adopted by various organisations. ILM also employs the ability to identify the potential of manager (Ortin-Angel \& Salas-Fumas, 1998). ILM at the manager level can develop more career structure for promotional and retention aspects (Morgan, 1990). Though ILM is based on incentive-based thinking, yet this classical model has retained its importance in internal management development leading to succession planning (Boxall \& Gilbert, 2007).

\section{RESEARCH METHODS AND MEASUREMENTS}

\section{Research Objective}

Researchers have found a need for further research on the involvement of leadership positions in the processes for improving TMS, which can lead to succession planning in an organisation (Groves, 2007). Considerable amount of research has discussed about succession planning as one of the important retention strategies (Golden, 2005; Hills, 2009; Perrin, 2005), but to our knowledge, there are no research on succession planning as the main objective of TMS for succession planning in an organisation. Therefore, the objective of this study is to investigate the relationship of TMS with succession planning in pharmaceutical companies in India. Furthermore, the study also attempted to find if talent retention strategies have a mediation effect on succession planning.

\section{Methodology}

The research is based on primary and secondary data. The responses were collected from 367 senior level managers of pharmaceutical companies in India who were on positions such as vice-president, associate director, vertical heads, etc. since it was believed that succession planning should extend down through the top 2-3 levels in larger organisations (Bernthal \& Wellins, 2006). Senior management, the highest layer of management in any organisation, are the ones responsible for department-related works and the ones who chartout plan for the organisation (Rothwell \& Kazanas, 1999). Generally, however, succession planning refers to special efforts to be invested in the best, highest performing, or highest potential talent at any organisational level or function, but 
particularly at or near the top (Barnett \& Davis, 2008). Data was collected from departments like sales, research and development, human resource management, legal compliances, etc. The total number of pharmaceutical companies was collected from the 2007 National Pharmaceutical Pricing Authority (NPPA) directory from the Department of Pharmaceuticals, Government of India. There were 266 pharmaceutical companies in Hyderabad, as mentioned in their addresses. Later as per the report of Dun \& Bradsteert (2016), ${ }^{1}$ on the top performer pharmaceutical companies in India, a list of 134 companies was taken. From those 134 companies, 15 pharmaceutical companies were selected, those who have more than 500 employees (Branine, 2008) and located in Hyderabad, which is hub of pharmaceuticals in India. The sample size should be of that much that makes the correct judgement on research. More data provides more correct judgement than less data (Kotrlik \& Higgins, 2001) The right formula and techniques are available for right size of data. Formula $N=\frac{Z^{2} * S^{2}}{e^{2}}$ was used, where " $z$ " is the standard score associated with confidence level $(95 \%$ in this case). As per cumulative normal distribution table, 1.96 is taken as the standard score (Cochran, 2007), ' $S$ ' is a standard deviation which represents variability in a given data set, that is computed as range divided by 6 . Range equals to $5-1=4$ (on a 5 points scale, range is computed as difference between maximum and minimum values). As per empirical rule in statistics, 6 refers to \pm 3 standard deviation values on the $x$-axis of the standard normal curve, which is common

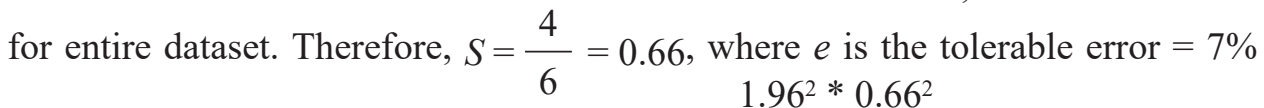
(Kotrlik \& Higgins, 2001). Sample size is $\mathrm{n}=\frac{1.96^{2} * 0.66^{2}}{0.07^{2}}=340$. In this case, it is taken around $10 \%$ of the sample size as buffer to deal with non-response; $340 * 8 \%=34$, therefore $340+34=374$, hence sample size was finalised on 374, whereas 367 complete responses were selected for analysis. The first communication with the respondents was developed through LinkedIn and then after taking their personal appointments, the details of the study were discussed with them. The variable for the study were selected from various seminal work in the area of TID, TD, TR, and succession planning as depicted in Table 1, and questionnaire was prepared. 
Table 1

Constructs and sources of items

\begin{tabular}{|c|c|c|}
\hline Construct & Items & Source \\
\hline TID & $\begin{array}{ll}\text { 1. } & \text { Leadership abilities } \\
\text { 2. } & \text { Systematic process } \\
\text { 3. } & \text { Performance rating } \\
\text { 4. } & \text { Career planning chart } \\
\text { 5. } & \text { Mentoring and coaching } \\
\text { 6. } & \text { Experience in company } \\
\text { 7. } & \text { Overall experience in industry } \\
\text { 8. } & \text { Critical nature of job } \\
\text { 9. Performance in critical incidents } \\
\text { 10. } & \text { Assessment centers } \\
\text { 11. } & \text { Competency mapping } \\
\text { 12. } & \text { Replacement chart }\end{array}$ & $\begin{array}{l}\text { - Hirsh, W. (2000). Succession } \\
\text { planning demystified. } \text { Brighton: } \\
\text { Institute for Employment Studies. } \\
\text { - Rothwell, W. (2010). Effective } \\
\text { succession planning: Ensuring } \\
\text { leadership continuity and building } \\
\text { talent from within. New York: } \\
\text { Amacom. }\end{array}$ \\
\hline TD & $\begin{array}{l}\text { 1. Continuous feedback } \\
\text { 2. Assessment development centers } \\
\text { 3. Individual development plan } \\
\text { 4. GAP in learning needs } \\
\text { 5. Competency development } \\
\text { 6. Higher education } \\
\text { 7. Cross functional assignments } \\
\text { 8. Job Rotation }\end{array}$ & $\begin{array}{l}\text { - Garavan, T. N., Carbery, R., } \\
\text { \& Rock, A. (2012). Mapping } \\
\text { talent development: Definition, } \\
\text { scope and architecture. European } \\
\text { Journal of Ttraining and } \\
\text { Development, 36(1), 5-24. } \\
\text { - Hirsh, W. (2000). Succession } \\
\text { planning demystified. Brighton: } \\
\text { Institute for Employment Studies. } \\
\text { - Rothwell, W. (2010). Effective } \\
\text { succession planning: Ensuring } \\
\text { leadership continuity and building } \\
\text { talent from within. New York: } \\
\text { Amacom. }\end{array}$ \\
\hline TR & $\begin{array}{l}\text { 1. } \text { Current compensation } \\
\text { 2. The reward system } \\
\text { 3. Work life balance facilities } \\
\text { 4. Employee engagement plans } \\
\text { 5. Transparent promotion policy } \\
\text { 6. Mentoring Facility } \\
\text { 7. Employer brand of my company } \\
\text { 8. Competency management } \\
\text { 9. Top level management } \\
\text { 10. }\end{array}$ & $\begin{array}{l}\text { Phillips, J. J., \& Edwards, L. } \\
\text { (2008). Managing talent retention: } \\
\text { An ROI approach. } \\
\text { San Francisco: John Wiley \& } \\
\text { Sons. } \\
\text { Hirsh, W. (2000). Succession } \\
\text { planning demystified. Brighton: } \\
\text { Institute for Employment Studies. }\end{array}$ \\
\hline $\begin{array}{l}\text { Succession } \\
\text { planning }\end{array}$ & $\begin{array}{l}\text { 1. Identification of successors } \\
\text { 2. Development of successors }\end{array}$ & $\begin{array}{l}\text { - Cannon, J. A., \& McGee, R. } \\
\text { (2010). Talent management and } \\
\text { succession planning (vol. 151). } \\
\text { London: Chartered Institute of } \\
\text { Personnel and Development. }\end{array}$ \\
\hline
\end{tabular}


The data was collected after the continuous follow up for five months. A pilot study was done on the sample of 105 to check the reliability of the questionnaire (Nunnally, 1978). The questionnaire was validated and the reliability scores of all the constructs were the Cronbach alpha value of TID .909, TD .939, TR .936, and SP .847. After clarifying that statements were clear to the respondents, the final survey was conducted. A hypothetical conceptual model was framed and validity of the model was tested. Structural equation modelling (SEM) was used to test the hypothetical model and structural relationship. SEM is a statistical tool that performs the structural relationship and factor analysis simultaneously (Hair et al., 2010). Confirmatory factor analysis (CFA) was used to evaluate the measurement model and structural relationship among variables. The relationship of sample and model constructs is confirmed by CFA by comparing the variance covariance matrix of both. The second stage SEM was built by using the structure model and measurement model. Second stage SEM is a combination of CFA, multiple regression, and path analysis. The mediation analysis was validated using SPSS 23 version.

\section{RESULTS}

The study has participants of two age brackets: 51\% (187) of respondents were between 20 to 39 years old of age while $49 \%$ (180) were between 40 to 60 years old. Similarly, out of 367 respondents, $50.95 \%$ were senior managers, $25.61 \%$ were head and vice presidents of different departments, $9.26 \%$ were directors, and $14.17 \%$ were others such as senior scientists, etc. Majority of the respondents $(85.29 \%)$ got promotion in the last five years. Out of 367 respondents, $90.19 \%$ (331) were identified for the future promotion. Employees who got the promotion or identified for the promotion in future were more associated with TMS, which are being practiced by their respective companies. The descriptive statistics of the data and the construct validity of constructs is reflected in Table 2. Construct reliability is measured using Cronbach's alpha. Cronbach's alpha is an important indicator of internal consistency. An alpha value of 0.7 and above indicates reliability of the construct (Fornell \& Larcker, 1981). From Table 2, it can be seen that all constructs have alpha score above 0.7 , hence reliability is supported. The construct validity of all other three construct is more than 0.50, except TID. According to Fornell and Larcker (1981), it is questionable if the construct validity (average variance extracted, AVE) is less than 0.50. It is seen in Table 2 that out of four constructs, TID does not fulfill the criterion. But AVE can be taken as a more conventional measure (Fornell \& Larcker, 1981), so research can be taken further if only reliability is acceptable. 
Table 2

Descriptive statistics and construct validity

\begin{tabular}{lcccc}
\hline Construct & Mean & SD & Cronbach's alpha & AVE (construct validity) \\
\hline TID & 3.73 & 0.413 & 0.888 & 0.40 \\
TD & 3.44 & 0.240 & 0.924 & 0.60 \\
TR & 3.80 & 0.230 & 0.906 & 0.50 \\
SP & 3.87 & 0.109 & 0.787 & 0.60 \\
\hline
\end{tabular}

Discriminant validity defines the extent to which the constructs of a model are truly different from each other. Discriminant validity of each construct was recognised by comparing the AVE and the squared inter-construct correlation as shown in Table 3. It is visible from Table 3 that the AVEs are more than the squared inter-construct correlations, which is required for the discriminant validity (Fornell \& Larcker, 1981).

Table 3

Discriminant validity

\begin{tabular}{lllll}
\hline Construct & TID & TD & TR & SP \\
\hline TID & 0.40 & & & \\
TD & 0.39 & 0.60 & & \\
TR & 0.36 & 0.47 & 0.50 & \\
SP & 0.34 & 0.29 & 0.50 & 0.60 \\
\hline
\end{tabular}

CFA was engaged in AMOS 24 to measure the fitness of the measurement model. All construct items (TID, TD, TR, and SP) were loaded in their corresponding constructs and were linked in a multi-dimensional way to confirm the model fitness. Factor loading of each item should be larger than 0.50 as per Fornell and Larker (1981) criterion, and model fitness indices must meet the criteria (Hair et al., 2010). There is a good fit between the theoretical model and sample data. Minimum discrepancy as indexed chi-square comparative fit index $(\mathrm{CFI})=0.83(>0.9)$ is moderate fit, Parsimonious normal fit index $(\mathrm{PNFI})=0.68$ $(>0.5)$ is good fit, and root mean residual $(\mathrm{RMR})=0.08(<0.08)$ is good fit. The minimum discrepancy per degree of freedom (CMIN/DF) is $4.93(<5)$, which is the level of acceptance as per many researchers (Wheaton et al., 1977). 
Table 4

The CFA outcome

\begin{tabular}{lcccc}
\hline Variable & $\begin{array}{c}\text { Number of original } \\
\text { items }\end{array}$ & $\begin{array}{c}\text { Number of items } \\
\text { retained }\end{array}$ & Factor loading & $p$-value \\
\hline
\end{tabular}

TID

12

12

The leadership abilities

$\begin{array}{ll}0.721 & * * * \\ 0.618 & * * * \\ 0.540 & * * * \\ 0.508 & * * * \\ 0.527 & * * * \\ 0.658 & * * * \\ 0.775 & * * * \\ 0.582 & * * * \\ 0.627 & * * * \\ 0.542 & * * * \\ 0.666 & * * * \\ 0.662 & * * *\end{array}$

systematic process of talent identification

performance rating

career planning chart

Mentoring and coaching

Experience in company

Overall experience in industry

Critical nature of job

Performance in critical incidents

Identification through assessment centers

Replacement charts 9

TD

Continuous feedback

Development centers

Individual development plan

Global job rotation

Gap in learning needs

Competence development

Higher education

Cross functional assignments

TR

Current compensation

Reward system

Work-life balance facilities

Employee engagement

Transparent promotion policy

Mentoring facility

Competency management

Employer brand

Top management

Organisational culture
0.809

0.738

0.91

0.875

0.654

0.769

0.71

0.73

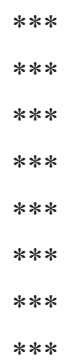

10

0.622

0.533

0.528

0.723

0.768

0.764

0.849

0.837

0.758

0.63

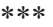

$* * *$

$* * *$

$* * *$

$* * *$

$* * *$

$* * *$

$* * *$

$* * *$

$* * *$

(continued on next page) 
Table 4: (continued)

\begin{tabular}{lcccc}
\hline Variable & $\begin{array}{c}\text { Number of original } \\
\text { items }\end{array}$ & $\begin{array}{c}\text { Number of items } \\
\text { retained }\end{array}$ & Factor loading & $p$-value \\
\hline SP & 2 & 2 & & $* * *$ \\
\multicolumn{2}{l}{ Identification of successors } & & 0.783 & $* * *$ \\
\multicolumn{2}{c}{ Development of successors } & & 0.829 & $* * *$ \\
\hline
\end{tabular}

Note: $* * * p<0.01$ significant at $0.01 \%$

The hypothesised model for the interrelationship between the constructs was checked by using SEM technique using AMOS 24. The measurement model was transformed into structural model, and as estimated the model achieved the fit indices and a good fit to the data (Hair et al., 2010). Minimum discrepancy as indexed chi-square CMIN/DF is $4.93(<5)$, which is an acceptable level (Wheaton et al., 1977), while CFI $=0.80(>0.9)$ is moderate fit, PNFI $=0.68$ $(>0.5)$ is good fit, and RMR $=0.08(<0.08)$ is good fit. Standardised regression weighs and significance values are referred to assess the strength and significance of hypothetical paths. As expected, TID is a significant and positive predictor of TR; TD is a significant and positive predictor of TR; TR is a significant and positive predictor of SP; TID is not a predicator of SP; and TD is not a predicator of SP. All these findings show that all the proposed relationships are accepted. Thus, TR mediated the relationship between TID, TD, and SP in pharmaceutical companies located in Hyderabad, India.

Table 5

Hypothesis testing results

\begin{tabular}{lc}
\hline Hypothesised path & Estimates \\
\hline TR $\leftarrow$ TID & 0.390 \\
TR $\leftarrow$ TD & 0.411 \\
SP $\leftarrow$ TR & 0.583 \\
SP $\leftarrow$ TID & 0.173 \\
SP $\leftarrow$ TD & 0.016 \\
\hline
\end{tabular}

As shown in Table 5, mediation effect of TR is there between TID and SP. The direct effect is insignificant $(\mathrm{B}=0.173)$ and indirect effect is significant $(\mathrm{B}=0.227)$. Similarly, between $\mathrm{TD}$ and $\mathrm{SP}$ direct effect is insignificant $(B=0.016)$ and indirect effect is significant $(B=0.240)$. Hence, TR mediates relationship between TID and SP, and TD and SP. 


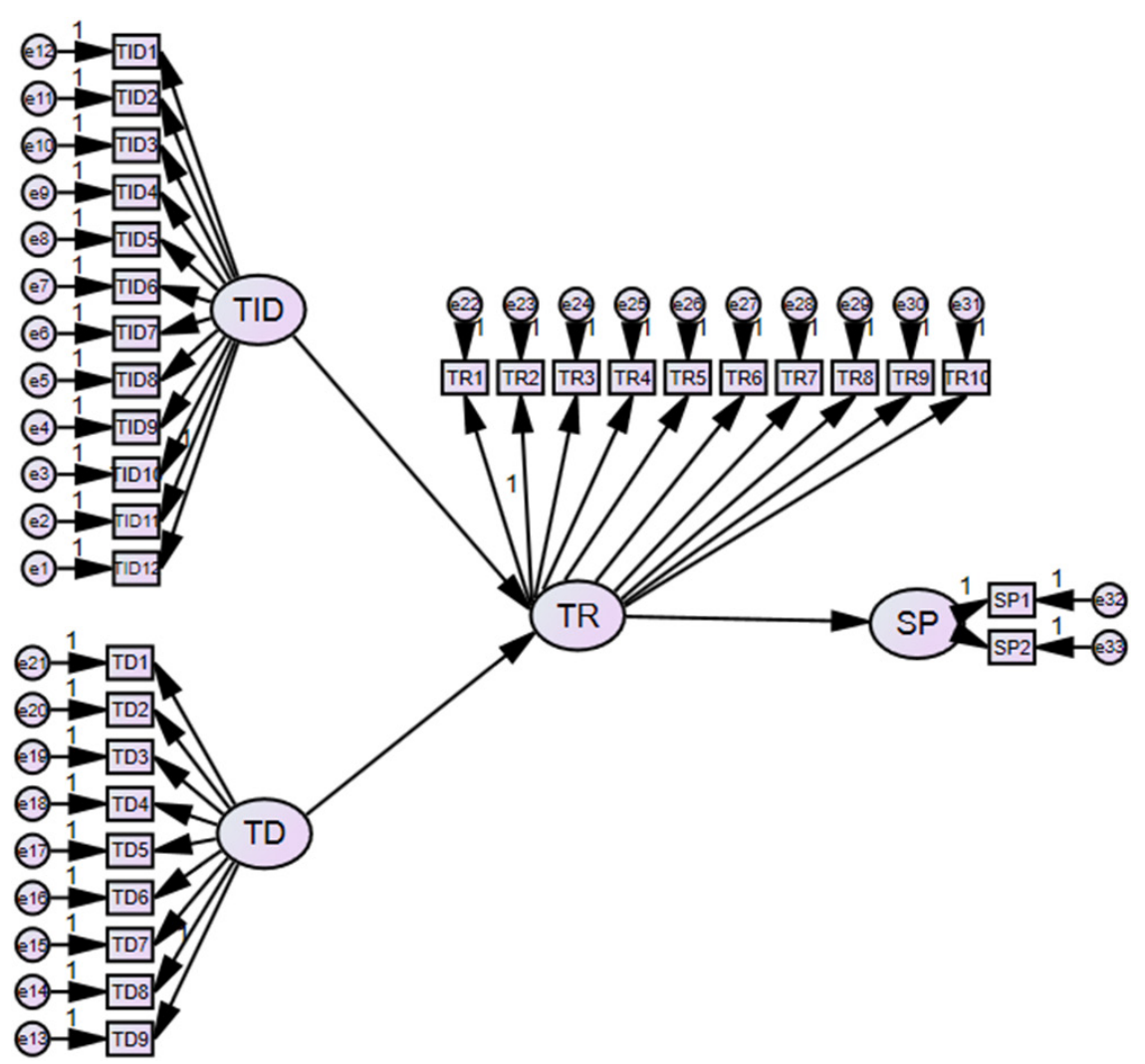

Figure 1. Hypothesised model

Table 6

The findings of mediation effect

\begin{tabular}{lcccc}
\hline Relationships (Path) & Direct effect & Indirect effect & Total effect & Result \\
\hline TID $\rightarrow$ SP & $0.173^{\text {ns }}$ & $0.227^{* *}$ & $0.401^{* *}$ & Full mediation \\
TD $\rightarrow$ SP & $0.016^{\text {ns }}$ & $0.240^{* *}$ & $0.253^{* *}$ & Full mediation \\
\hline
\end{tabular}

Note: ns $=$ non-significant effect; ${ }^{* *}$ significant effect

\section{DISCUSSION}

In today's business world, it is very important to build a pool of talent to fulfil the need for leaders in the organisations. The cutthroat competition in talent acquisition created a need for every organisation to be future ready to sustain and survive. To keep survival uplift in this scenario, one weapon is having the best 
talent management practices (Bratton \& Waton, 2018) and utilising the talent identification, development, and retention strategies to reduce employee turnover (Muhammad \& Shao, 2013) and support the talent pipeline. By keeping this in mind, the main objective of this study was to empirically test the relationship between TMS (TID, TD, TR) and succession planning. Overall, the study examined the relationship between TID, TD, and TR strategies and succession planning for leadership positions in pharmaceutical companies in Hyderabad. Results of the study indicate that although TID does not have direct significant relationship with succession planning, and it is established through TR. Hence, it is in line with the research that indicates a need of identification of potential employees and retain them (Barnett \& Davis, 2008) to create success in succession planning. The second hypothesis that focuses on direct relationship of TD and succession planning is also rejected, as their relationship is mediated by TR and indirect relationship was established. TR is reported as mediator between other TMS and succession planning in pharmaceutical companies. This is in line with other research work on relationship between succession planning and TMS with special reference to TR such as Nzuve and Omolo (2012), Govender (2010), Phillips et al. (2018), Mhlongo and Harunavamwe (2017), Rothwell (2010), and many others. The perfect succession planning will adopt the systems from TMS by identifying, developing, and retaining the key performers to fill in the key positions within organisation. Orellano and Miller (1997) state that the three basics of succession planning include identification of critical management positions within the organisation, identification of future vacancies in those positions, and identification and development of managers who would potentially fit into these vacancies when needed. Therefore, retention today is the strongest tool towards sustainability and ensuring competitive advantage (Bihani \& Dalal, 2014). This is also accentuated in the theory of ILM by utilising incentives and promotions within organisation (Baron \& Kreps, 1999). The results of the study build upon the theory of ILM by showing the importance of developing and retaining internal labour (senior managers in this study) for succession plan. The established SEM model also validated by the experts in the area and the results of the study were also appreciated by industry professionals working on succession plan management in pharmaceutical companies. This study can be concluded by saying that companies need to work on proper use of TID and TD strategies so that they will be able to retain their best talent since TID and TD are establishing direct positive relationship with TR. Once the high potential talent is retained, the probabilities of success of succession planning can increase (Harrison et al., 2006). When company has the right talent pool available, it is easy to place them on key positions whenever it is needed. Hence, it can be concluded that TR will be the key driver for succession planning in pharmaceutical companies. It is suggested to pharmaceutical 
companies to work on their TMS in such a way where the retention should be achieved by TID and TD which would further result in succession planning. Health and pharma sectors are prominent areas to conduct studies related with talent management (Turner, 2017). Hence, this study is also an important contribution to the practitioners and theorists working in the research area.

\section{CONCLUSION}

The study has symbolised a fair attempt to examine the relationship among TMS and succession planning of organisations. The findings of the research also suggested that the perception of employee about talent development activities has the link with their perception about their opportunities for career growth in the company. The impact of talent identification and development on succession planning was hypothesised to be indirect through talent retention. The results have also shown the contribution of TMS in the success of succession planning.

Though the study has shown a good result in term of using TMS as a whole for succession planning, it has some limitations. One of the limitations of the study is that it is a cross-sectional study, which can be overcome in future research by conducting longitudinal research to understand the impact of TMS on succession planning by collecting responses in different time periods and analyse whether succession planning actually has taken place because of TMS. The current study also does not put any light on the relationships of the demographics like age and year of experience, identified for promotions with TID, TD, TR, and succession planning. Future research can also include variables such as communication with employees regarding succession plans and its relationship with retention of employees. The study of succession planning can also cover about the continuity of workers, the continuity of skills (knowledge transfer), the continuity of social networks and professional contacts, and so much more. There is enormous scope of research in succession planning and retention. The sole use of self-report measures may lead to common method bias affecting the results although selfreport cannot be avoided in measuring employees' perception (Conway \& Lance, 2010). This study was only limited to the Hyderabad, India which may result in more generalisability of findings. Therefore, more research can be conducted on pharmaceutical companies all over India and internationally as well. Research can also be conducted in other industries like information technology, automobiles, etc. This study only covered the leadership positions in companies to check the relationship of TMS and succession planning, research can be done in future at all levels in organisation and not only on leadership roles as the manpower planning is unavoidable need on every level of employees. As organisations 
are investing so much on the development of their leaders and employees, there is a scope of study to see the impact of TMS not only on succession planning but on the other aspects of organisational success such as growth and financial performance of industry.

\section{NOTE}

1. Retrieved from https://www.dnb.com/business-directory/company-information. pharmaceutical_and_medicine_manufacturing.in.html?page $=6$

\section{REFERENCES}

Adebola, S. (2019). Why do organisations run talent programmes? Insights from UK organisations. In B. Adamsen \& S. Swailes (Eds.), Managing talent: Understanding critical perspectives (pp. 187-213). Cham: Palgrave Macmillan. https://doi.org/10.1007/978-3-319-95201-7_9

Ali, Z., \& Mehreen, A. (2019). Understanding succession planning as a combating strategy for turnover intentions. Journal of Advances in Management Research, 16(2), 216-233. https://doi.org/10.1108/JAMR-09-2018-0076

Armstrong, M. (2003). A handbook of human resource management practice (9th ed.). London: Kogan Page Publishing.

Atwood, C. G. (2007). Succession planning basics: A complete how-to guide. Alexandria, VA: American Society for Training and Development.

Axelrod, B., Handfield-Jones, H., \& Michaels, E. (2002). A new game plan for C players. Harvard Business Review, 80(1), 80-90.

Barnett, R., \& Davis, S. (2008). Creating greater success in succession planning. Advances in Developing Human Resources, 10(5), 721-739. https://doi.org/ $10.1177 / 1523422308322277$

Baron, J. N., \& D. M. Kreps. (1999). Strategic human resources: Frameworks for general managers. New York: Wiley.

Bassett, P., Buxton, C., Pathania, R., \& Sharan, M. (2005). Talent management is key to India's pharma future (pp. 3-5). Los Angeles, CA: Korn/Ferry International.

Bernthal, P., \& Wellins, R. (2006). Trends in leader development and succession. Human Resource Planning, 29(2).

Bihani, A., \& Dalal, K. (2014). A review into talent management, talent retention and its scope for learning organisations. International Journal of Knowledge Management and Practices, 2(1), 1-11.

Björkman, I., Ehrnrooth, M., Mäkelä, K., Smale, A., \& Sumelius, J. (2013). Talent or not? Employee reactions to talent identification. Human Resource Management, 52(2), 195-214. https://doi.org/10.1002/hrm.21525 
Bolander, P., Werr, A., \& Asplund, K. (2017). The practice of talent management: A framework and typology. Personnel Review, 46(8), 1523-1551. https://doi .org/10.1108/PR-02-2016-0037

Botha, A., Bussin, M., \& De Swardt, L. (2011). An employer brand predictive model for talent attraction and retention. SA Journal of Human Resource Management, 9(1), 1-12. https://doi.org/10.4102/sajhrm.v9i1.388

Boudreau, J. W., \& Ramstad, P. M. (2005). Talentship, talent segmentation, and sustainability: A new HR decision science paradigm for a new strategy definition. In Special Issue: The Future of Human Resource Management [Special Issue], Human Resource Management, 44(2), 129-136. https://doi .org/10.1002/hrm.20054

Boxall, P., \& Gilbert, J. (2007). The management of managers: A review and conceptual framework. International Journal of Management Reviews, 9(2), 95-115. https://doi.org/10.1111/j.1468-2370.2007.00203.x

Branine, M. (2008). Graduate recruitment and selection in the UK: A study of the recent changes in methods and expectations. Career Development International, 13(6), 497-513. https://doi.org/10.1108/13620430810901660

Bratton, J., \& Waton, S. (2018). Talent management, emotional labour and the role of line managers in the Scottish hospitality industry: A roundtable discussion. Worldwide Hospitality and Tourism Themes, 10(1), 57-68. https://doi.org/ 10.1108/WHATT-10-2017-0063

Buckley, P., Viechnicki, P., \& Barua, A. (2016). The 2016 Deloitte millennial survey winning over the next generation of leaders. Retrieved from https:/www2. deloitte.com/content/dam/Deloitte/global/Documents/About-Deloitte/gx -millenial-survey-2016-exec-summary.pdf

Burke, M., \& Day, R. (1986). A cumulative study of the effectiveness of managerial training. Journal of Applied Psychology, 71(2), 232-245. https://doi.org/10 $.1037 / 0021-9010.71 .2 .232$

Burney, S. (2016). An integrated conceptual model of performance appraisals and succession planning using multi valued evaluation. Pakistan Journal of Engineering, Technology \& Science, 2(2). https://doi.org/10.22555/pjets.v2i2.699

Cairns, T. D. (2009). Talent management at homeland security: A corporate model suggests a recipe for success. Employment Relations Today, 36(3), 19-26. https://doi.org/10.1002/ert.20257

Cannon, J. A., \& Mcgee, R. (2010). Talent management and succession planning (vol. 151). London: Chartered Institute of Personnel and Development.

Cappelli, P. (2008). Talent management for the twenty-first century. Harvard Business Review, 86(3), 74.

Cappelli, P. (2009). Talent on demand: Managing talent in an age of uncertainty. Strategic Direction, 25(3). https://doi.org/10.1108/sd.2009.05625cae.001

Charan, R. (2005). Ending the CEO succession crisis. Harvard Business Review, 83(2), $72-81$. 
Chitsaz-Isfahani, A., \& Boustani, H. R. (2014). Effects of talent management on employees retention: The mediate effect of organizational trust. International Journal of Academic Research in Economics and Management Sciences, 3(5), 114. https://doi.org/10.6007/IJAREMS/v3-i5/1196

CIPD. (2011). Learning and development survey 2011. London: CIPD.

Cochran, W. G. (2007). Sampling techniques. New York: John Wiley \& Sons.

Cohn, J. M., Khurana, R., \& Reeves, L. (2005). Growing talent as if your business depended on it. Harvard Business Review, 83(10), 62-71.

Collins, D., \& Holton, E. (2004). The effectiveness of managerial leadership development programs: A meta-analysis of studies from 1982-2001. Human Resource Development Quarterly, 15(2), 217-248. https://doi.org/10.1002/hrdq.1099

Collings, D. G., \& Mellahi, K. (2009). Strategic talent management: A review and research agenda. Human Resource Management Review, 19(4), 304-313. https://doi.org/10.1016/j.hrmr.2009.04.001

Conger, J. A., \& Fulmer, R. M. (2003). Developing your leadership pipeline. Harvard Business Review, 81(12), 76-85.

Conway, J. M., \& Lance, C. E. (2010). What reviewers should expect from authors regarding common method bias in organizational research. Journal of Business and Psychology, 25, 325-334. https://doi.org/10.1007/s10869-010 $-9181-6$

Davies, B., \& Davies, B. J. (2010). Talent management in academies. International Journal of Educational Management, 24(5), 418-426. https://doi.org/10.1108/ 09513541080000452

Day, D. (2001). Leadership development: A review in context. Leadership Quarterly, 11(4), 581-613. https://doi.org/10.1016/S1048-9843(00)00061-8

Doeringer, P. B., \& Piore, M. J. (1971). Internal labour markets and manpower analysis. Lexington, MA: Heath.

Dries, N. (2013). The psychology of talent management: A review and research agenda. Human Resource Management Review, 23(4), 272-285. https://doi.org/10 .1016/j.hrmr.2013.05.001

Farndale, E., Scullion, H., \& Sparrow, P. (2010). The role of the corporate HR function in global talent management. Journal of World Business, 45(2), 161-168. https://doi.org/10.1016/j.jwb.2009.09.012

Fegley, S. (2006). Talent management survey report, society for human resource management (SHRM). Retrieved from https://www.shrm.org.

Festing, M., \& Schäfer, L. (2014). Generational challenges to talent management: A framework for talent retention based on the psychological-contract perspective. Journal of World Business, 49(2), 262-271. https://doi.org/10 .1016/j.jwb.2013.11.010

Fink, D. (2010). The succession challenge: Building and sustaining leadership capacity through succession management. Thousand Oaks, CA: Sage Publications.

Fornell, C., \& Larcker, D. F. (1981). Structural equation models with unobservable variables and measurement error: Algebra and statistics. Journal of Marketing Research, 18(3), 382-388. 
Gandz, J. (2006). Talent development: The architecture of a talent pipeline that works. Ivey Business Journal Online, January/February, pp. 1-4.

Garavan, T. N., Carbery, R., \& Rock, A. (2012). Mapping talent development: Definition, scope and architecture. European Journal of Training and Development, 36(1), 5-24. https://doi.org/10.1108/03090591211192601

Ghee, W. Y., Ibrahim, M. D., \& Abdul-Halim, H. (2015). Family business succession planning: Unleashing the key factors of business performance. Asian Academy of Management Journal, 20(2), 103-126.

Gilding, M., Gregory, S., \& Cosson, B. (2015). Motives and outcomes in family business succession planning. Entrepreneurship Theory and Practice, 39(2), 299-312. https://doi.org/10.1111/etap.12040

Govender, I. (2010). Succession planning as a tool to minimise staff turnover rate: A case study of Nedbank homeloans, KZN operations. PhD dissertation, University of KwaZulu-Natal, Westville.

Golden, J. (2005). Talent management, succession planning, leadership development: What needed? Community \& Junior College Library, 13(4), 3-6. https://doi. org/10.1300/J107v13n04_02

Groves, K. S. (2007). Integrating leadership development and succession planning best practices. Journal of Management Development, 26(3), 239-260. https://doi.org/10.1108/02621710710732146

Hair, J. F., Anderson, R. E., Babin, B. J., \& Black, W. C. (2010). Multivariate data analysis: A global perspective (vol. 7). Upper Saddle River, NJ: Pearson.

Hall, D. T. (1986). Dilemmas in linking succession planning to individual executive learning. Human Resource Management, 25(2), 235-265. https://doi.org/10 $.1002 / \mathrm{hrm} .3930250206$

Handfield-Jones, H., Michaels, E., \& Axelrod, B. (2001). Talent management: A critical part of every leader's job. Ivey Business Journal, 66(2), 53-53.

Harrison, M., McKinnon, T., \& Terry, P. (2006). Effective succession planning. $T+D$, $60(10), 22-23$.

Heiden, S. (2007). Using a bottom-up approach to succession planning. Talent Management, 44-47.

Hills, A. (2009). Succession planning or smart talent management? Industrial and Commercial Training, 41(1), 3-8. https://doi.org/10.1108/00197850910927697

Hills, J. (2012). Neuroscience and talent: How neuroscience can increase successful execution of talent strategy. Human Resource Management International Digest, 20(3), 34-37. https://doi.org/10.1108/09670731211224375

Hirsh, W. (2000). Succession planning demystified. Brighton: Institute for Employment Studies.

Hor, F. C., Huang, L. C., Shih, H. S., Lee, Y. H., \& Stanley, L. E. (2010). Establishing talent management for company's succession planning through analytic network process: Application to an MNC semiconductor company in Taiwan. Computers and Mathematics with Applications, 60(3), 528-540. https://doi.org/10.1016/j.camwa.2010.05.001 
Huselid, M. A., Beatty, R. W., \& Becker, B. E. (2005). “A Players" or "A Positions"? The strategic logic of workforce management. Harvard Business Review, 83(12), 110-117.

Iles, P., Chuai, X., \& Preece, D. (2010). Talent management and HRM in multinational companies in Beijing: Definitions, differences and drivers. Journal of World Business, 45(2), 179-189. https://doi.org/10.1016/j.jwb.2009.09.014

Jindal, P., \& Nalluri, P. (2019). The motivational preferences of Gen Y: An empirical study on recent changes in motivation of gen Y. Gavesana Journal of Management, 11(1), 52-61.

Jindal, P., \& Shaikh, M. (2014). Social networking sites: Emerging as effective tools for attracting talent. Gavesana Journal of Management, 6(2), 48-55.

Jindal, P., \& Shaikh, M. (2015). A study of behavioral training as talent management strategy in organisations. Universal Journal of Management, 3(1), 1-6. https://doi.org/10.13189/ujm.2015.030101

Jindal, P., \& Shaikh, M. (2017). Developing and managing young talent: Framework of talent management strategies for Gen Y. International Journal of Environment, Workplace and Employment, 4(3), 171-185. https://doi.org/10 .1504/IJEWE.2017.087795

Jindal, P., Shaikh, M., \& Shashank, G. (2017). Employee engagement - Tool of talent retention: Study of a pharmaceutical company. SDMIMD Journal of Management, 8(2), 7-16. https://doi.org/10.18311/sdmimd/2017/18024

Johnson, R. D., Pepper, D., Adkins, J., \& Emejom, A. A. (2018). Succession planning for large and small organizations: A practical review of professional business corporations. In P. Gordon, \& J. Overbey (Eds.), Succession planning (pp. 23-40). Cham: Palgrave Macmillan. https://doi.org/10.1007/978-3-31972532-1_3

Johnston, K., Wattie, N., Schorer, J., \& Baker, J. (2018). Talent identification in sport: A systematic review. Sports Medicine, 48(1), 97-109. https://doi.org/10.1007/ s40279-017-0803-2

Jones, C. B. (2008). Chief nursing officer retention and turnover: A crisis brewing? Results of a national survey. Journal of Healthcare Management, 53(2), 89-105. https://doi.org/10.1097/00115514-200803000-00005

Kasper, S. M. (2008). Preparing for leadership transition: An examination of the impact of organizational communication in the administration of succession planning. PhD dissertation, Marshal Goldsmith School of Management, Fresno Campus, CA, USA.

King, K. A. (2016). The talent deal and journey: Understanding how employees respond to talent identification over time. Employee Relations, 38(1), 94-111. https://doi.org/10.1108/ER-07-2015-0155

Kotrlik, J. W. K. J. W., \& Higgins, C. C. H. C. C. (2001). Organizational research: Determining appropriate sample size in survey research appropriate sample size in survey research. Information Technology, Learning, and Performance Journal, 19(1), 43.

Kowalewski, S. J., \& Moretti, L. Succession planning: Current and future, p. 76. 
Kur, E., \& Bunning, R. (2002). Assuring corporate leadership for the future. Journal of Management Development, 21(9), 761-779. https://doi.org/10.1108/026217 10210448039

Larcker, D. F., \& Saslow, S. (2014). Report on senior executive succession planning and talent development. Institute of Executive Development and Stanford University. Retrieved from http://www.gsb.stanford.edu/faculty-research/ publications/2014-report-seniorexecutive-succession-planning-talentdevelopment

Lath, F., Koopmann, T., Faber, I., Baker, J., \& Schorer, J. (2021). Focusing on the coach's eye-towards a working model of coach decision-making in talent selection. Psychology of Sport and Exercise, 102011. https://doi.org/10.1016/j. psychsport.2021.102011

Lee, C., Liu, J., Rousseau, D. M., Hui, C., \& Chen, Z. X. (2011). Inducements, contributions, and fulfilment in new employee psychological contracts. Human Resource Management, 50, 201-226. https://doi.org/10.1002/hrm.20415

Leibman, M., Bruer, R. A., \& Maki, B. R. (1996). Succession management: The next generation of succession planning. People and Strategy, 19(3), 16.

Leslie, J. B., \& Palmisano, K. (2014). The leadership challenge in the pharmaceutical sector. Center for Creative Leadership, 2(1), 9-11. Retrieved from http://cclinnovation.org/wp-content/uploads/2020/03/leadership-challengepharmaceutical-center-for-creative leadership.pdf

Lewis, R. E., \& Heckman, R. J. (2006). Talent management: A critical review. Human Resource Management Review, 16(2), 139-154. https://doi.org/10.1016/j.hrmr .2006 .03 .001

Majumdar, D. M. (2007). Talent retention in pharmaceutical company: A perspective in the modern era. International Research Journal, II, (7).

Mäkelä, K., Björkman, I., \& Ehrnrooth, M. (2010). How do MNCs establish their talent pools? Influences on individuals' likelihood of being labeled as talent. Journal of World Business, 45(2), 134-142. https://doi.org/10.1016/j.jwb.2009 .09 .020

Marsick, V. J., \& Watkins, K. E. (2001). Informal and incidental learning. In S. B. Merriam (Ed.), The new update on adult learning theory, new directions for adult and continuing education (no. 89, pp. 25-34). San Francisco, CA: Jossey-Bass. https://doi.org/10.1002/ace.5

Mehrabani, S. E., \& Mohamad, N. A. (2011). Succession planning: A necessary process in today's organization. International Journal of e-Education, e-Business, e-Management and e-Learning, 1(5), 371.

Mellahi, K., \& Collings, D. G. (2010). The barriers to effective global talent management: The example of corporate élites in MNEs. Journal of World Business, 45(2), 143-149. https://doi.org/10.1016/j.jwb.2009.09.018

Mhlongo, S. B., \& Harunavamwe, M. (2017). Exploring management's perceptions of succession planning and its impact on staff retention at an agricultural company. International Journal of Research in Business Studies and Management, 4(3), 7-26. https://doi.org/10.22259/ijrbsm.0403002 
Miller, P. K., Cronin, C., \& Baker, G. (2015). Nurture, nature and some very dubious social skills: An interpretative phenomenological analysis of talent identification practices in elite English youth soccer. Qualitative Research in Sport, Exercise and Health, 7(5), 642-662. https://doi.org/10.1080/2159676X.2015 .1012544

Mokhber, M., Gi Gi, T., Abdul Rasid, S. Z., Vakilbashi, A., Mohd Zamil, N., \& Woon Seng, Y. (2017). Succession planning and family business performance in SMEs. Journal of Management Development, 36(3), 330-347. https://doi.org/10.1108/ JMD-12-2015-0171

Morfeld, C. (2005). Workforce planning: The strategy behind "strategic staffing". Retrieved from https://www.hr.com/en/communities/staffing_and_recruitment/workforceplanning-the-strategy-behind-strategic-s_eacytxwe.html

Morgan, G. (1990). Organizations in society. London: Macmillan International Higher Education. https://doi.org/10.1007/978-1-349-20779-4

Morton, L. (2004, January). Integrated and integrative talent management: A strategic HR framework. New York, NY: The Conference Board.

Muhammad, I. H., \& Shao, Y. (2013). The role of talent management and HR generic strategies for talent retention. African Journal of Business Management, 7(29), 2827-2835. https://doi.org/10.5897/AJBM2012.1369

Natarajan, S., \& Babu, S. (2018). A study on talent management practices for succession planning with reference to selected IT/ITES organizations in Coimbatore, Tamil Nadu. Prabandhan: Indian Journal of Management, 11(10), 54-62. https://doi.org/10.17010/pijom/2018/v11i10/132511

Novations. (2009). Talent development issues study. Long Island, NY: Novations Group.

Nunnally, J. C. (1978). Psychometric theory (2nd ed.). New York: McGraw-Hill.

Nzuve, S. N., \& Omolo, E. A. (2012). A study of the practice of the learning organization and its relationship to performance among Kenyan commercial banks. Problems of Management in the 21st Century, 4(July), 45-56. https://doi.org/ $10.33225 / \mathrm{pmc} / 12.04 .45$

O'Gorman, C. (2006). Strategy and the small business. In S. Carter, \& D. Jones-Evans (Eds.), Enterprise and small business (2nd ed., pp. 406-422). Harlow: Pearson.

Oladapo, V. (2014). The impact of talent management on retention. Journal of Business Studies Quarterly, 5(3), 19.

Orellano, T., \& Miller, J. (1997). Succession planning: Lessons from Kermit the frog. SHRM HR Resources Information Center.

Ortín-Angel, P., \& Salas-Fumas, V. (1998). Agency theory and internal labor. Journal of Economics and Management Engineering, 7(4), 573-613. https://doi.org/ $10.1162 / 105864098567524$

Pandita, D., \& Ray, S. (2018). Talent management and employee engagement: A metaanalysis of their impact on talent retention. Industrial and Commercial Training, 50(4), 185-199. https://doi.org/10.1108/ICT-09-2017-0073

Perrin, T. (2005). Winning strategies for a global workforce: Attracting, retaining, and engaging employees for competitive advantage. Towers Perrin Global Workforce Study, Executive Report TP449-05, Towers Perrin, Stamford, CT. 
Pfeifer, C. (2010). Determinants of promotions in an internal labour market. Schmalenbach Business Review, 62(4), 342-358. https://doi.org/10.1007/BF03396810

Phillips, J. J., \& Edwards, L. (2008). Managing talent retention: An ROI approach. San Francisco: John Wiley \& Sons.

Phillips, T., Evans, J. L., Tooley, S., \& Shirey, M. R. (2018). Nurse manager succession planning: A cost-benefit analysis. Journal of Nursing Management, 26(2,), 238243. https://doi.org/10.1111/jonm. 12512

Pruis, E. (2011). The five key principles for talent development. Industrial and Commercial Training, 43(4), 206-216. https://doi.org/10.1108/00197851111137825

Ramanaiah, G., \& Lavanya, L. (2011). A study on the level of commitment towards retention practices in IT and non-IT companies in Chennai. Advances in Management, 4(12), 53-56.

Rothwell, W. J., \& Kazanas, H. C. (1999). Building in-house leadership and management development programs: Their creation, management, and continuous improvement. Greenwood Publishing Group.

Rothwell, W. (2002). Putting success into your succession planning. Journal of Business Strategy, 23(3), 32. https://doi.org/10.1108/eb040249

Rothwell, W. (2010). Effective succession planning: Ensuring leadership continuity and building talent from within. New York: Amacom.

Sarmento, H., Anguera, M. T., Pereira, A., \& Araújo, D. (2018). Talent identification and development in male football: A systematic review. Sports Medicine, 48(4), 907-931. https://doi.org/10.1007/s40279-017-0851-7

Scullion, H., \& Collings, D. G. (2011). Global talent management: Introduction. In H. Scullion, \& D. G. Collings (Eds.), Global talent management (pp. 19-32). New York: Routledge. https://doi.org/10.4324/9780203865682

Stephens, N. (2010). Talent management: Ensuring your people give you the competitive edge. Strategic Direction, 26(7), 3-5. https://doi.org/10.1108/ 02580541011048948

Stroup, C., \& Zheng, H. (2016). What are key emerging, employee-facing trends in HR that will be influential in attracting and retaining future top talent? Cornell University ILR School Collection. 2016. Retrieved 20 April 2017 from http://digitalcommons.ilr.cornell.edu/student/?utm_source=digitalcommons. ilr.cornell.edu\%2Fstudent $\% 2$ F $127 \&$ utm_medium=PDF\&utm_campaign $=$ PDFCoverPages.

Stuart, S. (2012). Spencer stuart board index 2012. Retrieved 3 October 2019 from http://www.spencerstuart.com/

Sweeney, B. (2013). Success through succession: A review of recent literature. Queens University IRC. Retrieved from http://irc.queensu.ca/articles/success-through -successionreview-recent-literature.

Tangthong, S., Trimetsoontorn, J., \& Rojniruntikul, N. (2014). HRM practices and employee retention in Thailand: A literature review. International Journal of Trade, Economics and Finance, 5(2), 162-166. https://doi.org/10.7763/ IJTEF.2014.V5.362 
Turner, P. (2017). Talent management in healthcare: Exploring how the world's health service organisations attract, manage and develop talent. New York: Palgrave Macmillan.

Watson, W. T. (2016). Employee value proposition and total rewards: Modernize or risk irrelevance: Findings from the 2016 global talent management \& rewards and global workforce studies. London: Willis Towers Watson.

Webborn, N., Williams, A., McNamee, M., Bouchard, C., Pitsiladis, Y., Ahmetov, I., \& Dijkstra, P. (2015). Direct-to-consumer genetic testing for predicting sports performance and talent identification: Consensus statement. British Journal of Sports Medicine, 49(23), 1486-1491. https://doi.org/10.1136/ bjsports-2015-095343

Wenger, E., McDermott, R.A., \& Snyder, R. (2002). Cultivating communities of practice: A guide to managing knowledge. Boston, MA: Harvard Business School Publishing.

Wheaton, B., Muthen, B., Alwin, D. F., \& Summers, G. F. (1977). Assessing reliability and stability in panel models. Sociological Methodology, 8, 84-136. https://doi.org/10.2307/270754

Whelan, E., \& Carcary, M. (2011). Integrating talent and knowledge management: Where are the benefits? Journal of Knowledge Management, 15(4), 675-687. https://doi.org/10.1108/13673271111152018

Whelan, E., Collings, D., \& Donnellan, B. (2009, November). An examination of talent management concepts in knowledge intensive settings. In International Conference on Knowledge Science, Engineering and Management (pp. 450-457). Berlin, Heidelberg: Springer. https://doi.org/10.1007/978-3-642-10488-6_43

Wiblen, S. (2016). Framing the usefulness of eHRM in talent management: A case study of talent identification in a professional services firm. Canadian Journal of Administrative Sciences, 33(2), 95-107. https://doi.org/10.1002/cjas.1378

Yadav, S. S., \& Shankar, R. (2017). Succession planning: Some lessons. Journal of Advances in Management Research, 14(4), 406-407. https://doi.org/10.1108/ JAMR-07-2017-0081 